\title{
The separation of a phenol-degradable bacterium and its application on coke wastewater treatment by using microbial fuel cell technology
}

\author{
Peng Guo, Yuhan Du, Li Zhang, Lijian Guo, Fang Lv \\ Hebei College of Industry and Technology, Shijiazhuang 050091, China \\ guopeng.sci@gmail.com
}

\begin{abstract}
Keywords: phenol-degradable bacterium; coke wastewater treatment; microbial fuel cell Abstract. Phenol is the major organic compound of coking wastewater. It is of biochemical toxicity, difficult processing, difficulty to be degraded and high cost in the treatments. Microbial fuel cell (MFC) is a new type of fuel cell. It can produce electron in the process of metabolism of electricigens and export it to the external circuit. In this study, a phenol-degradable bacterium was separated and purified (Pseudomonas sp.) at first. Then, a dual chamber type of MFC was established and phenol was selected as fuel. Afterward, we optimized the operation condition. Then, based on the character of coking wastewater, different types and concentrations of metal ions which were existed were added to research the influences of metal ion on the characteristics of electricity generation of MFC. This study showed that the strain can utilize phenol as sole carbon source, and can degrade over $98 \%$ of phenol $\left(1000 \mathrm{mg} \cdot \mathrm{L}^{-1}\right)$ within $72 \mathrm{~h}$. Meanwhile, it has higher phenol tolerance up to $1750 \mathrm{mg} \cdot \mathrm{L}^{-1}$. The optimal condition is $\mathrm{pH}$ value of 8.0 . Furthermore, $\mathrm{Fe}^{3+}$ accelerated the electron generation and phenol decomposition, while $\mathrm{Cu}^{2+}$ and $\mathrm{Mn}^{2+}$ inhibited them. Additionally, as a type of surface active agent, Tween -80 influenced the best concentration is 100 $\mathrm{mg} /(\mathrm{L} \cdot \mathrm{d})$. Finally, sodium alginate was used as immobilized reagent and it can accelerate electricity production capacity.
\end{abstract}

\section{Introduction}

Coking wastewater is a typical toxic organic wastewater which is difficult to be degraded[1]. It mainly comes from the production process of the coke oven gas, the production of water and steam condensate. Its characteristics are high concentration of pollutants, toxic and difficult to degrade. At present, the deep treatment method of coking wastewater generally includes the following several kinds: biochemical method, adsorption method, membrane separation method, advanced oxidation process and coagulation precipitation method. The treatment method of coking wastewater treatment in the world is the biochemical treatment process of aerobic activated sludge. In recent years, with the environmental protection agency on the water safety calls for more and more intense, many manufacturers began to proceed in activated sludge process for coking wastewater treatment process of the subsequent section increased ozone oxidation and activated carbon adsorption and other high technology content depth processing technology, the treatment of wastewater in the chroma and chemical oxygen demand (COD) to have obvious improvement [2].

Microbial fuel cells (MFCs), as a promising technology for treating wastewater while recovering bioenergy, have also been studied to remove nitrogen. MFCs are bioelectrochemical reactors in which bacteria oxidize various organic or inorganic compounds in the anode and produce protons and electrons that transport to the cathode to reduce oxygen to water [3]. Electron flow from the anode to the cathode generates an electric current or power if a load is connected. MFCs have the potential to function as either the secondary treatment in municipal wastewater treatment or as the primary treatment process for decentralized communities or industry, simultaneously cleaning wastewater and producing bioenergy [4].

MFC technologies are a promising and yet completely different approach to wastewater treatment as the treatment process can become a method of capturing energy in the form of electricity or hydrogen gas, rather than a drain on electrical energy. In the late 1990s, Kim and coworkers demonstrated that bacteria could be used in a biofuel cell as a method of determining the concentration of lactate in water and then that electricity generation in an MFC could be sustained by starch using an industrial wastewater [5]. MFC treatment may be utilized to replace or 
supplement conventional secondary treatment systems and minimize the overall costs associated with aeration, secondary clarification, and secondary sludge treatment [6]. MFC technology exploits biological fermentation and respiratory mechanisms to directly recover energy as electricity during the degradation of organic matter contained in wastewater and/or sludge [7]. Relative to conventional primary and secondary treatment processes, MFC systems also have the benefit of reducing overall operational costs because aeration is not needed [8]. In addition, lower overall sludge volumes can be realized because the growth of secondary biomass is limited under anaerobic MFC conditions.

In this work, we used MFCs technology to treat coking wastewater. At first, we optimized the operation condition and then researched on the influence of metal ions and immobilized reagent on it.

\section{Materials and methods}

\section{Separation of bacterium}

Carbon clothes $(4 \times 7.5 \mathrm{~cm})$ as cathode and anode electrode were immersed in acetone for $3 \mathrm{~h}$ to removing oil soluble substances from the surface, boiled by deioned water for $2 \mathrm{~h}$ and then drought by oven at $120{ }^{\circ} \mathrm{C}$ for 30 minutes. Proton exchange membrane (PEM, Nafion ${ }^{\circledR}$ ink) were sequentially set in boiled $\mathrm{H}_{2} \mathrm{O}_{2}$ solution, $\mathrm{H}_{2} \mathrm{SO}_{4}$ solution for $1 \mathrm{~h}$, cleaned by deioned water, and finally reserved in deioned water. Activate sludge was collected from a treatments tank in a coking plant. The sludge was then diluted 10 times by water. Phenol was added to diluted sludge until 500 $\mathrm{mg} / \mathrm{L}$. which was the anolyte of MFC. Meanwhile, $\mathrm{K}_{3} \mathrm{Fe}(\mathrm{CN})_{6}$ solutions with the concentration of $50 \mathrm{mmol} / \mathrm{L}$ were selected as cathode solution.

When it worked, anolyte $(250 \mathrm{~mL})$ and cathode solution $(250 \mathrm{~mL})$ were poured into glasses. These solutions were separated by PEM. Carbon clothes were immersed into the solutions. Anode and cathode were connected to an external resistance of $1000 \Omega$. After $72 \mathrm{~h}$, anolyte were transfer to bacteria agar plate $\left(\mathrm{Na}_{2} \mathrm{HPO}_{4} 4.090 \mathrm{~g} / \mathrm{L}, \mathrm{NaH}_{2} \mathrm{PO}_{4} 2.544 \mathrm{~g} / \mathrm{L}, \mathrm{NH}_{4} \mathrm{Cl} 0.3 \mathrm{~g} / \mathrm{L}, \mathrm{KCl} 0.1 \mathrm{~g} / \mathrm{L}, \mathrm{NaCl}\right.$ $5.85 \mathrm{~g} / \mathrm{L}$, phenol $1000 \mathrm{mg} / \mathrm{L}$ and glucose $0.5 \mathrm{~g} / \mathrm{L}$ ) to separate and purify bacteria. The purified bacteria were identified by $16 \mathrm{~s}$ rDNA.
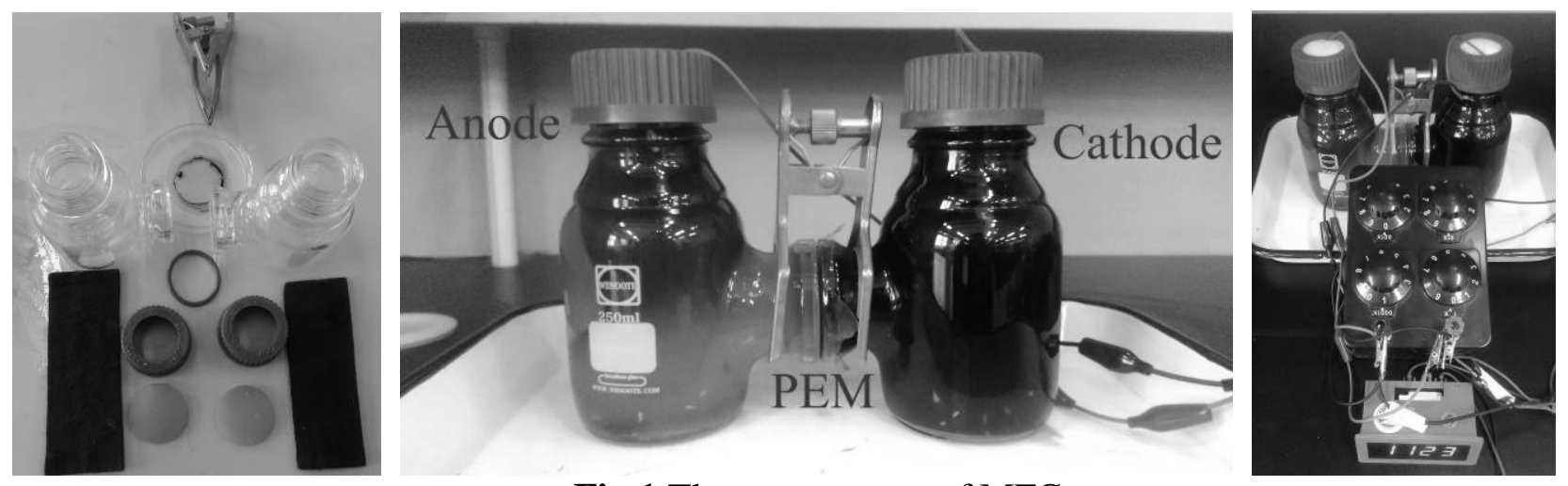

Fig.1 The components of MFC.

Influences of different factors on the MFC

To study the influences of different factors on the MFC, different factors were set such as $\mathrm{pH}$, surface active agent, immobilized reagent, as well as the concentration of metal ions which usually exist in coking wastewaters. In this work, the purified bacteria were proliferated in flask till the values of $\mathrm{OD}_{600}$ to 0.500 . Then it was diluted 10 times by medium $\left(\mathrm{Na}_{2} \mathrm{HPO}_{4} 4.090 \mathrm{~g} / \mathrm{L}, \mathrm{NaH}_{2} \mathrm{PO}_{4}\right.$ $2.544 \mathrm{~g} / \mathrm{L}, \mathrm{NH}_{4} \mathrm{Cl} 0.3 \mathrm{~g} / \mathrm{L}, \mathrm{KCl} 0.1 \mathrm{~g} / \mathrm{L}, \mathrm{NaCl} 5.85 \mathrm{~g} / \mathrm{L}$, phenol $1000 \mathrm{mg} / \mathrm{L}$ and glucose $0.5 \mathrm{~g} / \mathrm{L}$ ) and treated as anolyte. The factors were listed in Table 1. 
Table 1 Treatments setting of the MFC.

\begin{tabular}{lll}
\hline Item & Value in coking wastewater & Treatments setting \\
\hline $\mathrm{pH}$ & $7-8.5$ & $6.00,8.00$ and 10.00 \\
Tween -80 & - & 10,50 and $100 \mathrm{mg} / \mathrm{L}$ \\
Sodium alginate & - & $10: 1,20: 1$ and $50: 1$ \\
$\mathrm{Fe}^{3+}$ & $44-260 \mathrm{mg} / \mathrm{L}$ & $100,250,500 \mathrm{mg} / \mathrm{L}$ \\
$\mathrm{Cu}^{2+}$ & $0.06-2.2 \mathrm{mg} / \mathrm{L}$ & $0.5,1.0$ and $2.0 \mathrm{mg} / \mathrm{L}$ \\
$\mathrm{Mn}^{2+}$ & $1.5-4.9 \mathrm{mg} / \mathrm{L}$ & $0.5,2.0$ and $5.0 \mathrm{mg} / \mathrm{L}$ \\
\hline
\end{tabular}

During the study, voltage was recorded every hour during the experiment. Meanwhile, the concentration of phenol was determined by 4-aminoantipyrine method [9]. The power density of the MFC at different external resistances was determined using the polarization curve measurements. The external resistance was changed from 10 to $10,000 \Omega$, and the corresponding voltage generated was measured using a multimeter. The data were taken after the readings stabilized. Based on the external resistance and the voltage, the current density generated was calculated according to Eq. (1) and the power density $(P),\left(\mathrm{W} / \mathrm{m}^{2}\right)$ was calculated according to Eq. (2).

$$
\begin{aligned}
& I=V /(\mathrm{A} \times R) \\
& P=V \times I=V^{2} /(\mathrm{A} \times R)
\end{aligned}
$$

Where $\mathrm{R}$ is the resistance, $V$ is the voltage, and $\mathrm{A}$ is the area of the anode.

All data were determined in quadruplicate.

\section{Results}

In this study, a phonel-degradable bacterium was isolated. It was identified as Pseudomonas sp.. It could degrade phonel 82.7 after $8 \mathrm{~h}$ and over $98 \%$ in $72 \mathrm{~h}$ at the original concentration of 1000 $\mathrm{mg} / \mathrm{L}$. Meanwhile, it has higher phenol tolerance up to $1750 \mathrm{mg} \cdot \mathrm{L}^{-1}$.

In this study, current density reached the highest values after $8 \mathrm{~h}$. In all the treatments, the treatment with the $\mathrm{pH}$ value of 8.00 showed the highest degradation rate, voltage and current density. Tween addition also affected the running of MFC. The highest values were shown in the treatment of the concentrations of $50 \mathrm{mg} / \mathrm{L}$. Sodium alginate accelerated degradation rate in all treatments. However, the voltage and current density were much lower than those of CK (Table 2).

\begin{tabular}{|c|c|c|c|c|c|c|c|c|c|c|}
\hline & \multirow{2}{*}{ CK } & \multicolumn{3}{|c|}{$\mathrm{pH}$ of medium } & \multicolumn{3}{|c|}{ Tween-80 (mg/L) } & \multicolumn{3}{|c|}{ Sodium alginate ratio } \\
\hline & & 6.00 & 8.00 & 10.00 & 10 & 50 & 100 & $10: 1$ & $20: 1$ & $50: 1$ \\
\hline $\begin{array}{l}\text { Degradation } \\
\text { rate }(\%)\end{array}$ & 82.7 & 82.1 & 84.5 & 83.5 & 80.5 & 89.9 & 86.0 & 89.0 & 91.7 & 89.6 \\
\hline Voltage (mV) & 612 & 560 & 670 & 382 & 569 & 681 & 310 & 501 & 561 & 310 \\
\hline $\begin{array}{l}\text { Current density } \\
\left(\mathrm{W} / \mathrm{m}^{2}\right)\end{array}$ & 0.125 & 0.105 & 0.150 & 0.049 & 0.107 & 0.154 & 0.032 & 0.087 & 0.105 & 0.032 \\
\hline
\end{tabular}

Table 2 The changes of MFC under different $\mathrm{pH}$, Tween- 80 and sodium alginate after $8 \mathrm{~h}$ running.

Table 3 The changes of MFC after different metal ions additions after $8 \mathrm{~h}$ running.

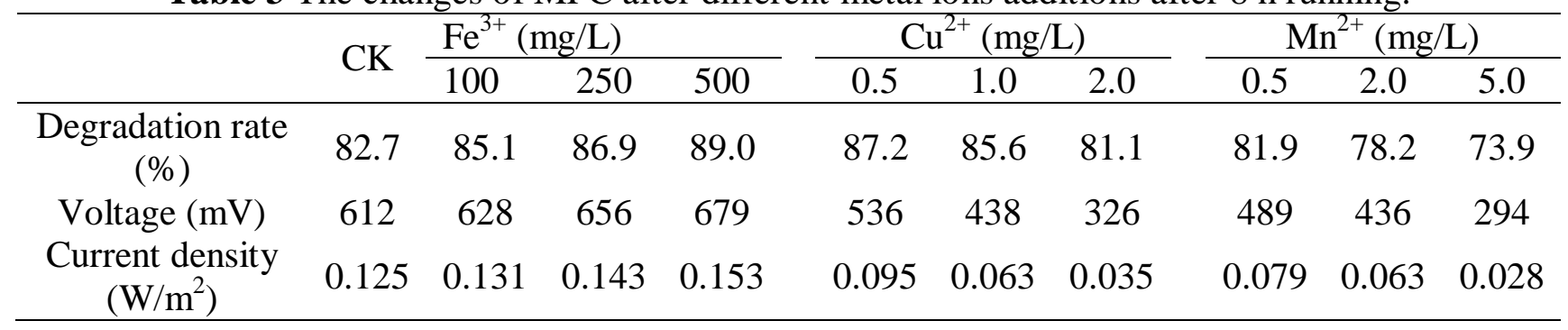


Metal ions addition also affected the values of MFC, but changed differently. $\mathrm{Fe}^{3+}$ addition accelerated phonel and current density. Higher concentration induced higher values. Lower $\mathrm{Cu}^{2+}$ addition accelerated phonel degradation but the voltage and current density declined. $\mathrm{Mn}^{2+}$ addition revealed significantly negative effects on MFC function, both in phonel and current density (Table 3).

\section{Discussion}

As a phonel-degradable bacterium, Pseudomonas sp. also showed electricity generation ability. Current generated in a MFC is limited by two factors: (i) oxidization rate of substrate by bacteria and (ii) rate of electrons transfer to the electrode surface.

The value of $\mathrm{pH}$ was an important factor that affected MFC. In a MFC, the anode reactions produce protons and the cathode reactions consume protons. Accumulation of protons due to slow and incomplete proton diffusion and migration through the membrane will cause a $\mathrm{pH}$ decrease in the anode chamber $[10,11]$. Higher $\mathrm{pH}$ value may be benefit for the transfer of proton which may lead to the decline of internal resistance. However, bacterium can only survive in suitable $\mathrm{pH}$ conditions. Extreme high or lower would destroy its cell membrane and induce its activities decline. In this study, the best $\mathrm{pH}$ was 8.00 , which was close to the natural $\mathrm{pH}$ of wastewater $(\mathrm{pH}=7.80)$.

It was reported that surfactants can change the cell membrane ultrastructure to form trans-membrane channels, which was effective for enhancing the permeability of microbial cells, reducing the resistance of membranes, expediting the transport of matters through the cell membranes, and increasing the degradation of substrates [12]. In this work, we found the increases of voltage and current density after the addition of Tween- 80 with the amount of $50 \mathrm{mg} / \mathrm{L}$. It was similar to the report of Wen et al. [13]. However, extreme higher surfactants addition induced drastic declines of current density, while the degradation rates also declined. That may be because surfactants destroy the cell structure and decline their metabolism.

Immobilization techniques provided an alternative solution. They have been widely applied to wastewater treatment, such as phenol degradation [14], nitrogen removal [15] and sulfate reduction [16]. The application of immobilized microorganism not only helps maintain high bacterial cell concentrations, but also increases the biological activity of the microorganisms, makes control separation easy, and protects cells against toxic substances and changes in environment factors. Sodium alginate as a natural polysaccharide, which has concentrated solution, gelation and film-forming ability, is an environment-friendly material, so was widely used in food, medicine, textile, printing and dyeing, daily chemical products [17]. In this work, sodium alginate did accelerated degradation rates, but more sodium alginate addition may infect the rate. Futthermore, it showed obvious neegative effect on current density. The reason may be the addition of stabilizer induced the increases of internal resistance.

In this work, $\mathrm{Fe}^{3+}$ addition accelerated degradation rate and current density. That may because it was the essential element for microbes. Differently, lower $\mathrm{Cu}^{2+}$ addition accelerated degradation as it was also an important element. However, higher $\mathrm{Cu}^{2+}$ inhibited the degradation. $\mathrm{Cu}^{2+}$ is one common harmful heavy metals in wastewater. In the acclimated activated sludge system, the influences can be controlled by changing the environmental factors. The toxic effect of $\mathrm{Cu}^{2+}$ in activated sludge was shown in weak acid and alkaline conditions. When $\mathrm{pH}$ was above $7.5, \mathrm{Cu}^{2+}$ could transfer into $\mathrm{Cu}(\mathrm{OH})_{2}$ and decrease the toxicity. However, the dissolved $\mathrm{Cu}^{2+}$ can also cause the irreversible protein denaturation, which will affect the biological activity. $\mathrm{Mn}^{2+}$ was a toxic metal ion. Its addition obvioisly declined degradation rate and current density.

\section{Summary}

Many factors affect the operation of MFC. Surfactants addition accelerated current density but decreased degradation $100 \mathrm{mg} /(\mathrm{L} \cdot \mathrm{d})$. On the contrary, stabilizer decreased current density but accelerated degradation and the best ratio was $20: 1 . \mathrm{Fe}^{3+}$ accelerated the electron generation and phenol decomposition, while $\mathrm{Cu}^{2+}$ and $\mathrm{Mn}^{2+}$ inhibited them. However, as many types of metal ions 
in the coking wastewater, the influences of others such asCa ${ }^{2+}, \mathrm{Zn}^{2+}, \mathrm{Ni}^{+}$and $\mathrm{Mg}^{2+}$ should also be researched.

\section{Acknowledgements}

This work was financially supported by the Scientific Foundation for the Introduction of Researcher of Hebei College of Industry and Technology, China (No. BZ1101), Foundation on the science and technology of the University of Hebei Province, China (No. QN2015081) and the Scientific Foundation for Teachers of Hebei College of Industry and Technology, China (No. QZ-1303).

\section{References}

[1] L. Huang, X. Yang, X. Quan, J, Chen and F. Yang: J. Chem Technol. Biot. Vol. 85 (2010), p. 621-7

[2] L. Huang, S. Cheng and G. Chen: J. Chem Technol. Biot. Vol. 86 (2011), p. 481-91

[3] F. Zhang, and Z. He: J. Chem Technol. Biot. Vol. 87 (2012), p. 153-9

[4] L.M. Tender, C.E. Reimers, H.A, Stecher, D.E. Holmes, D.R. Bond, D.A. Lowy, K. Pilobello,S. J. Fertig and D. R. Lovley: Nat. Biotechnol. Vol. 20 (2002), p. 821-5

[5] H. Joo, M.S. Hyun, I.S. Chang, and B.H. Kim: J. Microbiol. Biotechn. Vol. 9 (1999), p. 365-7

[6] S.I. Ishii, S. Suzuki, T.M. Norden-Krichmar, K.H.Nealson, Y.Sekiguchi, Y.A.Gorby and O. Bretschger: Plos. One Vol. 7 (2012), p. e30495

[7] W. Rulkens: Energ. Fuel Vol. 22 (2007), p. 9-15

[8] R.A. Rozendal, H.V.M. Hamelers, K. Rabaey, J. Keller and C.J.N. Buisman: Trends Biotechnol. Vol. 26 (2008), p. 450-9

[9] G. Buitron, M.E. Schoeb, I. Moreno-Andrade and J.A. Moreno: Water Res. Vol. 39 (2005), p. 1015-24

[10] L. Zhuang, S. Zhou, Y. Li and Y. Yuan: Bioresource Technol. Vol. 101 (2010), p. 3514-9

[11] R.A. Rozendal, H.V. Hamelers and C.J. Buisman: Sci. Technol. Vol. 40 (2006), p. 5206-11

[12] Q. Wen, Y. Wu, D. Cao, L. Zhao and Q. Sun: Bioresource Technol. Vol. 100 (2009), p. 4171-5

[13] Q. Wen, F. Kong, F. Ma, Y. Ren and Z. Pan: J. Power Sources. Vol. 196 (2011), p. 899-904

[14] Y.J. Liu, A.N. Zhang and X.C. Wang: Biochem. Eng. J. Vol. 44 (2009), 187-92

[15] W.M. Rostron, D.C. Stuckey and A.A. Young: Nitrification of high strength ammonia wastewaters: comparative study of immobilisation media. Water Res. Vol. 35 (2001), p. 1169-78

[16] H-F. Hsu, Y-S. Jhuo, M. Kumar, Y-S Ma and J-G. Lin: Bioresource Technol. Vol. 101 (2010), p. 4354-61

[17] L. Lu, M. Zhao, G-F. Li, J. Li, T-N. Wang, D-B. Li and T-F. Xu: Catal. Commun. Vol. 26 (2012), p. 58-62 